This item was submitted to Loughborough's Research Repository by the author.

Items in Figshare are protected by copyright, with all rights reserved, unless otherwise indicated.

\title{
The impact of National Qualifications Frameworks: by which yardstick do we measure dreams?
}

\section{PLEASE CITE THE PUBLISHED VERSION}

http://dx.doi.org/10.1080/13639080.2015.1122178

\section{PUBLISHER}

(C) Taylor and Francis

\section{VERSION}

AM (Accepted Manuscript)

\section{PUBLISHER STATEMENT}

This work is made available according to the conditions of the Creative Commons Attribution-NonCommercialNoDerivatives 4.0 International (CC BY-NC-ND 4.0) licence. Full details of this licence are available at: https://creativecommons.org/licenses/by-nc-nd/4.0/

\section{LICENCE}

CC BY-NC-ND 4.0

\section{REPOSITORY RECORD}

Pilcher, Nick, Scott Fernie, and Karen L. Smith. 2019. "The Impact of National Qualifications Frameworks: By Which Yardstick Do We Measure Dreams?”. figshare. https://hdl.handle.net/2134/20944. 


\title{
The impact of National Qualifications Frameworks: by which yardstick do we measure dreams?
}

\begin{abstract}
National Qualifications Frameworks (NQFs) are a global phenomenon. This is evidenced by their scale, coverage and intrinsic link with education policy across Europe and beyond. Research into their impact has encompassed a number of perspectives; theoretical, practical and evaluative. Yet, despite the existence of critical literature related to the development, design and impact of NQFs, little research has questioned the actual feasibility of researching the 'impact' of NQFs per se. The arguments in this paper position such research as both unfeasible and futile: a dream for which it is impossible to identify a suitable yardstick to measure. We base our argument around three broad themes: linguistics and semantics; homogeneity and; methodological complexity. Around these themes we aim to show why such research has proved problematic and, in doing so, contribute to the field as it explores the impact of NQFs in the future.
\end{abstract}

Key words: National Qualifications Frameworks; impact

Nick Pilcher, School of Marketing Tourism and Languages, Edinburgh Napier University

Scott Fernie, School of Civil and Building Engineering, Loughborough University

Karen Smith, School of Education, University of Hertfordshire

\section{Introduction}

The 'impact' of National Qualifications Frameworks (hereafter referred to as NQF for cases of singular or adjectival reference, and NQFs for cases of plural reference) has been much researched. Some research notes the difficulty of finding evidence of the 'impact' of NQFs, whether national, continental or global (e.g. Raffe 2012; Coles 2007; Young and Allais 2011). Elsewhere, the paucity of, and call for more research into, the 'impact' of NQFs is noted (Allais, 2011; Keevy 2010; Raffe 2012; Fernie et al. 2013). Some research outlines theoretical perspectives to research NQFs (e.g. Fernie and Pilcher 2009) or talks of the 'success' (Young 2003; Raffe 2003), 'failure' (Allais 2007a; Keating 2003) or limited 'impact' of NQF (Fernie et al. 2013). There are ostensibly many reasons why the 'impact' of NQFs is researched. Governments will wish to measure the 'impact' of NQFs given their role in a neo-liberal form of education (Allais 2003; Keating 2011; Strathdee 2011) where "education is presented as the solution to unemployment" (Allais 2007b, 67). NQFs are, further, an intrinsic part of the aims and objectives of Bologna (Bologna Process 2009, van der Wende, 2000). They play a key role in the external management of education through their relationship with quality assurance, and will thus be something governments wish to measure the 'impact' of (cf. Salter and Tapper 2000; Strydom et al. 2004). They are ostensibly intended to standardize qualifications in a way to ensure improved employability of neo-liberal subjects (cf. Clegg 2010). Further, the spread of NQFs 
has been such that in 2011 over 100 countries were at some stage of implementing an NQF (Young and Allais 2011). Institutional support for attempts to measure the impact of NQFs have come from various state institutions such as the International Labour Organization (ILO) in collaboration with the European Training Foundation (ETF) in 2009 (Young and Allais 2011) and the UK based Economic and Social Research Council (ESRC) (e.g. project number PTA 026 -27 - 2166). Evaluating the impact of NQFs is thus considered important and its occurrence is not surprising given the scale of investment in designing and diffusing NQF.

Yet, despite the existence of critical literature on NQFs per se (for example regarding the difficulty of standardising the qualification levels of very different subjects (e.g. Blackmur 2004)), little research has considered the actual feasibility of researching the impact of NQFs. We do this here. We argue that such research is both unfeasible and actually futile: a dream for which it is impossible to identify a suitable yardstick to measure. The article constitutes a rejoinder to those arguing there are viable perspectives to research NQFs (e.g. Fernie and Pilcher 2009) or that claim to measure 'impact' (e.g. Fernie et al. 2013). We base our argument around three broad themes of linguistics and semantics; homogeneity and; methodological complexity. Such themes could be argued to be applicable to critique other forms of system-wide education research such as the value of ranking systems or student survey responses, but here we focus them specifically on the concept of 'impact' and how it operates in the context of NQFs. Is it valuable to write such an article though? Is there any value in saying something has no value? We believe there is, for two reasons: firstly to show why researching the impact of NQFs has proven problematic, and secondly (and more importantly) to expose the limited return from research that attempts to measure the 'impact' of NQFs.

\section{Linguistic and semantic considerations related to 'impact' in the context of NQF}

Words can be extremely slippery (Moon 2002), especially as they have multiple meanings, or 'heteroglossia' (Bakhtin 1981). Depending on their background and context, words become "symbols that assume a shared memory" (Borges 1979, 33). Such a shared memory can only be deconstructed or explored through dialogue (Bakhtin 1981) and without such dialogue the word becomes 'neutral' (Bakhtin 1986) or 'neutralized': devoid of context or significance. Many misunderstandings arise from misassumptions that language is more tangible than assumed. As Saussure rightly noted: “all the mistakes in our terminology, all our incorrect ways of naming things that pertain to language, stem from the involuntary supposition that the linguistic phenomenon must have substance” (Saussure 1959, 89). Further, language is very much associated with power through ideologically informed words and discourse (Fairclough 2006).

Regarding the term 'impact', the Oxford Dictionary defines 'impact' as "Come into forcible contact with another object" or "have a strong effect on someone or something” (Oxford Dictionaries, n.d.). In the context of NQFs, arguably, to have 
'impact', NQFs need to have a strong effect on something or someone. They also, arguably, need to be "managed as a complex change, involving not just different paperwork, but a transformation in the way that people think" (Bennet and Ryley 2007, 202). Yet, for this to happen, it is essential that dialogue (cf. Bakhtin 1981) and engagement occurs between NQFs and the people and organisations they are attempting to 'impact' upon. However, such dialogue, by way of introducing a 'new order of things' (Machiavelli 1532), could actually, and has actually, created 'resistance.' In Australia, the first 'wave' (see below) of its NQF “contributed toward sectoral isolation” (Keating 2003, 285) and a later proposed NQF evoked opposition from Australia's elite universities as they perceived it to threaten their autonomy (Wheelahan, 2011, 323). In Scotland, its NQF has been passively resisted as merely a tick-box exercise (Fernie et al. 2013), akin to an 'audit culture' (cf. Bennet and Ryley 2007) and something of which Hodson and Thomas (2003, 383) would say was only "policy in name... [that]... do[es] little to disturb the thinking and operational activity of academic groups.” Given the managerialist vision (Magalhaes and Amaral 2007) served by NQFs and the intrinsic link they have with quality assurance which takes away much of the control and direction of academic decisions from academics (Salter and Tapper 2000), it is no surprise that they incur resistance. Nor are NQFs always 'voluntary'; Raffe et al. (2008, 67) note of countries mapping their own NQF on to the European Qualifications Framework (EQF) that: "countries which do not take part may find it harder to benefit from European funding, conceptual support, common learning and coordination, to the extent that these rely on the language of the EQF". Hardly 'voluntary' then and unlikely to be met with no 'resistance'. Also, perhaps, something which explains why the uptake of NQFs has been so rapid and widespread, especially given the backdrop of such motivations in line with Bologna's drive to make European education as a whole more competitive (van der Wende, 2000). Thus, from a linguistic and semantic perspective, paradoxically, 'impact' could arguably be measured as 'resistance' (cf. Foucault, 2000).

The semantic complexity is increased when it is considered that any 'impact' could be perceived negatively, as 'impact' could prevent the development of new courses, or mean courses are managerially described in ways which confound academics (cf. Fernie et al. 2013). Furthermore, 'resistance' itself, far from being negative, could actually be positive, "because important educational purposes are being defended" (Young 2008, 133). Thus, semantically, it is also unclear what criteria or interests should shape 'impact' or 'resistance' as being 'positive' or 'negative'.

Another semantic paradox of 'impact' is that a more 'successful' framework could be argued to be one that has virtually no 'impact'. For example, the heavy 'impact' of outcomes-based frameworks (see below) could actually "undermine the provision of education" (Allais 2007b, 66) whereas, in a 'communications-based' type framework (see below), a lack of 'impact' is actually equated with success. Indeed, as the Scottish Credit and Qualifications Framework (SCQF) "had little impact on many colleges and universities in the short term," (Raffe et al. 2008, 65) this helped its 
introduction, as little resistance, which would normally be faced by a more top-down regulatory approach, was encountered (Young 2011, 227). Generally, "the success of a communications framework must be set against its relatively modest ambition and the fact that it only facilitates changes which do not challenge the existing distribution of power” (Raffe 2011, 297). Hence, with the NQF 'success' stories of Scotland, New Zealand, and Ireland (Young 2003), 'success' is judged by a lack of 'impact.' Conversely, 'failure' has been accorded to NQFs that have attempted to have too much 'impact', and been too ambitious in introducing new qualifications, resulting in a confusing mass of descriptors for irrelevant qualifications not taken up by anyone (Allais 2007a, b). Thus, paradoxically, from a semantic perspective, for an NQF, having no 'impact' can equal 'success', but having significant 'impact' can equal 'failure'.

Another key linguistic element with researching 'impact' is precisely who or what the NQF is having an 'impact' on. With some NQFs, the 'impact' could be different on stakeholders in Further Education (FE) than in Higher Education (HE); regarding the SCQF, the willingness (or not) of universities to give credit to entrants with Higher National Certificates or Higher National Diplomas obtained in FE colleges (Maclennan et al. 2000; Fernie et al. 2013) means its 'impact' can be greater on some entrants than on others. Further, the HE sector is often not homogenous and will be 'impacted' on differently. In the UK, for instance, it is likely that 'corporate universities' need to pay less attention to Academic Freedom issues than others (Neave 2002 (cf. the resistance to the NQF in independent schools at a secondary level (Raffe 2007)) and are thus less affected by any NQF. Another semantic complexity is that the concept of 'learner' is continually changing; for example, Ireland's rapidly changing workforce means its learner base is becoming far more diverse and changing greatly now, meaning it "must be supported in a framework that emphasises a learner-centred approach” (Tierney and Clarke 2008, 138). There is moreover little discussion of the term 'impact' from a stakeholder perspective in the literature, yet, arguably, a governmental understanding of 'impact' could differ greatly from a learner or lecturer understanding (cf. Borges 1979). Without the semantic ability to define the target of 'stakeholder' that the impact of NQFs should be on (whether institutional or personal) it is clearly a problematic evaluation activity.

A related linguistic issue regarding any research into the impact of NQFs is the nature and volume of language used to describe NQFs. Although some research claims NQFs bring great clarity about programmes and qualifications that would be otherwise "impenetrable” to end users (Bjørnåvold and Coles 2008, 231), and that a clear aim of NQFs is transparency (Coles, on behalf of Clark, 2010, 6, van der Wende, 2000), some 'failing' frameworks (e.g. the South African NQF) are described as being victim of a "spiral of specification" (Allais 2007b, 73). Similarly, in Australia, "the rhetoric in the area of qualifications is unavoidably loaded with jargon that limits its audience” (Keating 2011, 293). With 'outcomes-based' frameworks, "outcomes or competence statements tend to proliferate over specified, detailed, 
unwieldy, narrow documents....the very length and complexity... makes them relatively unintelligible to anyone other than those involved in standards design” (Allais 2011, 247).

In meta-frameworks, such as the EQF, the EQF "table, with descriptors for the reference levels, is by far the most comprehensively annotated table in Europe" (Markowitsch and Luomi-Messere, 2008, 33) and thus highly text heavy. Regarding the nature of such language, the discourse of NQFs and quality documents are packed with what Findlow $(2008,324)$ refers to as a "non-productive linguistic game... whereby documents are written on the pretence, or assumption, that different shareholders are using the same language to reflect common understandings" (cf. Borges 1979). Indeed, although Tuck (2007, V) notes that "the value of an NQF lies in its potential to contribute to policy goals such as lifelong learning, recognition of skills, or improving the quality of education and training”, how these terms are defined or measured is not considered (see the section on methodological considerations below). Similarly, 'credit' could be defined differently in vocational and non-vocational frameworks; non-vocational European Credit and Transfer accumulation System credits being oriented to study programmes, but vocational European Credit system for Vocational and Educational Training credits defined in relation to qualifications (Dunkel and Le Mouillour 2008, 196). Even the measurement of credits can differ both across and even within institutions (Rehburg 2005). Thus, linguistically, the nature and volume of language used in NQFs mitigate against any attempt to measure their impact.

The actual national language also conflates complexities. Key NQF terminology can have different meanings across languages, for example, "the English term 'competences' describes not the learning process but its outcome, whereas the German word is input-oriented” (Bohlinger 2008, 106). Even in a single language, terminology is vague, in the Australian NQF, for example, the descriptor "offers only a relatively vague description of the horizontal articulation and credit transfer arrangements" (Keating 2003, 281). Similarly, in Botswana, "from a technical point of view, unit standards have been resisted partly because of the opaque language" (Tau and Modesto 2011, 370). Regarding vocational descriptions, different sources of training for "one and the same training level can lead to completely different skills / competences, and these can on no account be regarded as equivalents” (Markowitsch and Luomi-Messerer 2008, 52). Thus, the complexity of key NQF terminology can mean different users have different interpretations (cf. Borges 1979) which cannot be understood by end users, thereby presenting barriers to any broad measurement of 'impact'.

Overall, linguistically and semantically, the term 'impact' has numerous complexities. Semantically, an NQF could, paradoxically, have greater 'impact' if it fails to have any 'impact'. Also, it is unclear who defines or is considered the subject of 'impact'. Such lack of clarity is further compounded by: words having different meanings in different languages; different meanings between stakeholders in the same language; 
the nature and volume of language used to describe key areas of NQFs differing; and key terms differing in use across different parts of the globe. Thus, any consideration of 'impact' and related areas from a linguistic and semantic perspective highlight that any attempt to measure 'impact' is an impossible dream. This is even clearer when the (lack of) homogeneity of NQFs is considered.

\section{A consideration of the (lack of) homogeneity of NQFs}

Much has been written on the complexity and different types of frameworks in individual articles, but not with a view to drawing attention to the implications of these for any attempt to measure 'impact'. We do this here from a number of considerations: the motivations for NQFs; the different classifications and descriptions of NQFs and; the complexity of change itself.

Motivations to introduce (or have) an NQF are numerous. Many countries introduce an NQF after being influenced by their rhetoric, and implement them through policy borrowing, "without considering differences in contexts, and without understanding all aspects of how the framework was developed and implemented" (Allais 2011, 254). NQFs range from those that "have largely been organic in their formation, those that have emerged in response to the EQF, and those that have emerged as part of the worldwide movement towards NQFs” (Keating 2011, 397). Further, these motivations could be voluntary or not, for example some NQFs may have been related to the EQF under certain duress, (cf. Raffe 2008) and following the implicit or explicit goals of Bologna for qualification homogeneity, transferability (van der Wende, 2000, Bologna Process 2009) or marketization (Dobbins and Knill, 2007). Or perhaps simply by following what neighbours are doing (Cohen-Vogel and Ingle, 2007). In the case of Lithuania, "relating the NQF to the EQF may threaten Lithuanian national and ethnic identity and the cultures of smaller ethnic groups within the country's borders” (Tutlys and Spudyte 2011, 445) and therefore not be something done voluntarily. Also, motivations may be perceived differently. For example, with 'one' (see below) of South Africa's NQF, some research notes it to be 'nation-building' in rationale and linked with a neo-liberal outcomes -based education (Allais 2003). In contrast, other research describes the same South African NQF as being socially reconstructive (Granville 2003).

Often, motivations for NQFs are grounded in political agendas of neo-liberalism (e.g. New Zealand (Phillips 2003)), to reduce trade union influence (e.g. England (Allais, 2011)), to marketize education (cf. van de Wende, 2000, Young, 2011,), or simply as “a policy-shaping instrument” (e.g. France (Bouder 2003, 350)). Yet, politics changes over time and thus alters the NQF being measured for 'impact'. In any case, NQFs do change over time regardless of their link to policy. At first, an NQF may be used to collate qualifications, then once established, be used to accredit work-based learning. Further, the scale and expectation of what the NQF will do vary greatly. Some countries have ambitious motivations: in Slovenia, the NQF is "intended to develop and not merely classify qualifications” (Hozjan 2008, 147). Other countries have 
similar aspirations (e.g. Lithuania (Tutlys and Spudyte 2011)) and in Scotland the NQF encompasses all levels of education. Here there is a much debated (e.g. Cedefop 2008; Young 2011) and highly ambitious goal to "promote parity of esteem between academic and vocational qualifications” (Raffe 2003, 254). However, other countries have far more limited NQFs, such as Botswana (Tau and Modesto 2011) and New Zealand (Phillips 2003).

Raffe notes NQFs must also consider a "trade-off between the scope of a qualifications framework and its prescriptiveness" (Raffe 2003, 241) whereby “the more stringent the design rules of a framework, the harder it is to achieve wide coverage” (Raffe et al. 2007). In Scotland, the SCQF never represented, nor was intended to represent, a new order of things. Instead, it was grafted on to what already existed, and "it was therefore almost impossible for the SCQF to take on a life of its own” (Young 2008, 131). It is only a 'well-established' (Brown 2010; Raffe et al. 2008) framework because, paradoxically (cf. success equalling no impact (above)) it never needed to 'well-establish' itself.

Differing motivations for NQFs also influence their heterogeneity. In France, "many vested interests are at work" (Bouder 2003, 355) given the NQF developed from the amalgamation of two very different systems of classification: one that focused on function and state, and the other on fields of specialisation. Tuck (2007) argues that despite different definitions of NQFs causing confusion, "the important point is that the nature and design of the NQF should be based on the goals that policy makers seek to achieve by introducing an NQF" (Tuck 2007, V). Yet the above shows heterogeneous policy goals for NQFs, making it impossible to ascertain their 'impact' given the different motivations for their introduction. It would, for example, be inappropriate to measure the 'impact' of the Slovenian NQF alongside the Scottish NQF, as their aims differ significantly.

Yet, the heterogeneity of NQFs is clear with even a cursory glance at the different classifications and descriptions used in and for NQFs. NQFs are 'strong' or weak'; 'comprehensive' or 'partial'; 'instruments of regulation' or 'instruments of communication’ (Young 2003); 'weak’ or 'loose’ (Wheelahan 2011); 'loose’ or 'tight' (Tuck 2007); based on qualifications or on the units that constitute them (Young 2008). NQFs are ‘communications-based' or 'outcomes-based' (Allais 2011), 'detailed' or 'simplistic' (Allais 2003); they are 'descriptive' (e.g the SCQF (Raffe 2003)) or 'regulatory'. They are of perhaps three types: ‘communications’ NQFs (e.g. the SCQF) for informing people of qualifications, 'reforming' NQFs (e.g. the Irish QF), aimed to improve existing systems, or 'transformational' NQFs (e.g. the SAQA), working toward a proposed future system (Raffe 2011). Furthermore, as Raffe (2011, 285) notes, these "three types are best understood as ideal types... they represent points along a continuum”. A further complication Raffe (2011) notes is that all NQFs may encompass a range of sub-NQFs, and these may have hierarchies of importance. NQFs could also be hybrids, for example, the Mauritian NQF has succeeded in its role as an 'organizing framework' but failed as an 'outcomes-based' NQF (Marock 
2011). The way NQFs use specific terms also differs. For example, the use of 'vertical' and 'horizontal' can refer to types of qualifications (Bouder 2003; Keating 2003), to comparison between them (Marock 2011), to partnerships between industry and education (Hozjan 2008), or to mobility of workers (Paulsen 2008). Furthermore, some NQFs could espouse to be one type, yet in reality be a different type: even NQFs which claim to be 'simplistic' are often 'complex' as their "qualifications specify the curriculum in a great deal of detail, while claiming not to” (Allais 2003, 313).

Another influencing factor on the classification and nature of NQFs is 'time'. Firstly, NQFs change over time; the NQFs adopted in Malaysia, Mauritius and Botswana are described as 'second generation' frameworks, as opposed to the 'first generation' frameworks in Scotland, Australia, New Zealand, South Africa and England (Allais 2011). Similarly, in Australia, the NQF established in 1995 was a 'first generation' NQF, but proposals were later made for a new 'strengthened' and clearly different NQF (Wheelahan 2011). In South Africa there have been a number of NQF versions $(1.0 ; 1.2$ and 2.0) and South Africa is now in its third 'generation' of NQF (Keevy 2010). Indeed, even when argued to have failed (Republic of South Africa 2001), or to have been "deeply problematic” (Ensor 2003, 337) NQFs have still continued in development and had qualifications added (Allais 2007a). Other descriptions of evolving NQFs also describe different avatars of NQFs but use other terms apart from 'generation'. One description is in terms of 'waves' with 'old', 'second' wave, and 'middle level' NQFs (Keating 2011). Notably, these 'waves' come after each other and contain substantially different NQFs. In South Africa, following the 'failure' of the first generation of NQF, a new Act was passed in 2008, "which substantially changed the NQF as well as the organisations responsible for it. Before these changes could be implemented, the structures of government were changed in 2009, and the NQF is changing accordingly" (Allais 2011, 344). These changing classifications over time create a moving target for impact. There will also be many proponents and detractors of either the old or the new NQF (cf. Machiavelli 1532), as indeed Strathdee notes in the case of New Zealand (Strathdee 2011).

Secondly, 'time' also plays a key role in itself in any measurement of 'impact' as, "it takes time to develop and implement an NQF” (Raffe et al. 2008, 65; cf. Young 2008) and assessing the impact of a recently introduced framework is difficult if it is in "the early stages of development” (Allais 2011, 238). Indeed, the "long timescale” (Young and Allais 2011, 209) available was a key factor in the ostensible 'success' of the SCQF (Allais 2010). 'Time' also relates to implementation of change and how it relates to 'impact'. Implementing change is complex in any context, but, "managing change in education is more complex and requires a different "toolkit" than managing change within business” (Grant 2003, 82). Indeed, even literature which fully supports 'change' to improve quality in education notes it is "a slow and demanding task” (Strydom et al. 2004, 210). All these complications created by such 'time’ 
related factors underline the impossibility of developing a yardstick to measure 'impact'.

In summary, there is a significant lack of homogeneity regarding NQFs. Further, how descriptions are used varies and frameworks often exist on a continuum rather than as delineable entities. Moreover, complexities of 'time'-related elements make any attempt to measure 'impact' problematic given that each NQF will have a different 'impact'. When the complexities of the heterogeneity of NQFs is compounded by the complexities of the linguistic considerations described earlier, it is clear, we argue, that there is no yardstick with which we can measure the 'impact' of NQFs.

\section{Methodological complexities of researching the 'impact' of NQFs}

The difficulty of collecting evidence for the 'impact' of NQFs has been noted. Writing about a large International Labour Organization funded project that sought to measure the 'impact' of NQF in 16 different countries, Young $(2011,224)$ writes of (what we term) the practical, method-related "extremely difficult task" of collecting reliable evidence (Young 2011, 224). Allais (2011, 237) writes of (what we term) a more methodological, or philosophical issue that "any comparative educational research is a limited, complex, and fraught endeavour" (Allais 2011, 237). We categorise the issues we raise below as being broadly of these two types: methodological or philosophical related, and method or practical related.

In terms of methodological or philosophical issues, a key issue is that any research into NQFs be 'independent' (Blackmur 2004). Yet, often the 'independence' of such investigating bodies can be questioned (e.g. the fact that the Scottish Government funds research into the impact, use, and integration of the SCQF (see Worth Doing 2008). Thus, there is here a danger of producing what Hartley (2006) has described as policy-informed evidence rather than evidence-informed policy, as a result of the fact that policy makers will only commission research that they think will provide the evidence they need to support their policy. Also, philosophically related, from who do the objectives of NQFs come? If they come from the governors and the leaders will their objectives be the same as those of the learners? Of the lecturers? And so, philosophically, who is the 'impact' assessed for?

There is also the Nietzschean dilemma of whether it is cause or effect being measured (cf. Nietszsche 1888). Philosophically, are we measuring the impact of NQFs on an education system, or measuring the existence of NQFs as a reflection of how we perceive education differently in a world where people increasingly want to change jobs (cf. Calleja 2008; cf. Lauder 2011). Secondly, whether we are measuring the impact of NQFs on education, or the impact of education on NQFs. The Slovenian NQF was developed after the EQF, so do we measure the 'impact' of the EQF on the Slovenian NQF, the impact of the Slovenian education system on the Slovenian NQF, or the impact of the Slovenian NQF on the Slovenian education system? As Allais 
notes, NQFs "are arguably the product of global comparisons and internationalisation as much as they are an object of study within these areas” (Allais 2011, 238).

Also philosophically, it is impossible to determine whether 'impact' has been the result of an NQF, or a consequence of other factors. As Phillips notes of changes in New Zealand, it is hard to ascertain whether such change, "is a direct result of the NQF and associated qualifications reforms or a consequence of a range of different economic and social influences is hard to determine” (Phillips 2003, 300).

Philosophically, it is also arguable that NQFs themselves are pursuing impossible dreams, ones for which there is no yardstick to measure the 'impact' of. One is that of trying to allow the same 'level' of qualifications from each institution to represent the same 'value'. The different natures of individual economies and governments and the way companies are competing for employees (Lauder 2011) means an honours or master's degree from the elite institutions carries far more weight than those from the non-elite institutions, thus making it philosophically impossible to equate them. The fact that NQFs are inextricably linked to economic policy is also a key element, as they are tied with the exact nature of the knowledge and skills required for the global economy, and, given the nature of the global economy's direction to divide employees into A, B and C categories and for certain employers to only recruit from the elitist universities in a 'war for talent', the ethics behind NQFs may be grounded in "a fundamental misreading of the key trends in the global economy" (Lauder 2011, 213). Thus, the ostensible equality that NQFs purport to bring to qualifications from different institutions in terms of what they show learners can do can be seen from this perspective as a façade.

What is more, universities themselves are complicit in and promote such elitism "as higher education has become a global business. The branding of universities and faculty members is integral to the organization of academic enquiry” (Lauder 2011, 119). Thus, many graduates from non-elite universities may well have the same number of credits and the same level of qualifications and outcomes, but in terms of the top companies "many able will not get their foot in the door" (Lauder 2011, 219). This is arguably made even more complex when universities are opening more and more campuses in other countries and forming partnership agreements with universities in other countries. Further, the huge differences in university governance systems and levels of academic freedom in different countries within the EU (Karran 2007) provide a further complexity of national contexts in which to measure impact given that some countries (e.g. Spain, Germany, Australia) are far more federal than are others (e.g England, Scotland, Serbia). Any attempt to measure 'impact' is thus faced with the methodological challenge of considering these differing contexts and policies, not least in terms of how they make it philosophically impossible to standardise qualifications and which, given the scale of the differences in contexts is of such complexity as to make it an impossible dream. 
Another impossible dream that NQFs attempt to pursue relates to their link to Quality Assurance (QA), which has been argued to be, certainly in the case of the English experience "a limited means of ensuring high quality in the teaching process" (Filippakou and Tapper 2007, 355 [italics in original]). Not only this, but the concept of what quality is and how it should be measured has "persistently escaped answer" (NAB 1984, as quoted in Silver and Silver 1986, 9) and is no easier to "describe and discuss than to deliver in practice" (Gibson 1986, 129). Indeed, it is even possible that "the procedures we use to measure standards may become more important than the things we are measuring, so that we lose sight of the purpose of our measurement" (Ramsden 1986, 107). As Allais rightly observes, "quality assurance systems do not build quality, they build procedures that claim to measure quality” (Allais 2011, 251).

Further, in addition to issues with the very concept of QA itself, the ability of NQFs to play a role in QA has been questioned (Blackmur 2010), and their association with QA and the UK's Quality Assurance Agency (QAA) may lead to resistance from academics, given the fact that "many academics were bitterly opposed to the QAA regime” at its inception (Filippakou and Tapper 2007, 346). Indeed, some research calls for a reflection and stocktaking of quality assurance, from the viewpoint that current approaches are not working (Liesner 2006; Blackmur 2010). To actually judge and trust a qualification depends, as Young (2011) notes, on "factors that are not expressed in the written outcomes and cannot be 'written down'” (Young 2011, 266), and many performances cannot be written down or captured in text: "any claim that 'written outcomes'... are based on a scientific and objective methodology is false; this claim has no basis” (Young 2011, 270).

Arguably, it is also significantly problematic, if not impossible, to measure and convey different qualifications using different level sets, or compare different degrees on the same level. As Blackmur $(2004,109)$ notes, comparatively, a Masters by Research Thesis, and a Masters of Business Administration would be placed on exactly the same levels on an NQF, yet "nobody with even a passing knowledge of the nature of an MA and an MBA would claim that they are equivalent in any meaningful sense.” Regarding how different frameworks interact with each other, how is it philosophically possible for the Irish NQF's 10 levels, the Scottish NQF's 12 levels, and the England, Wales and Northern Ireland NQF's 8 levels to map onto the 10 levels of the EQF to interact with each other? If this cannot be ascertained, how then is 'impact' to be measured? It is in itself an "extremely radical” assumption with "far-reaching implications" (Young 2003, 225) in itself.

Regarding practical or method related issues, there is the practical issue of isolating exactly what the NQF is having an 'impact' on. For example, in the case of Australia, Keating notes that "It is impossible to locate the impact of the AQF on these [technical and further education related] developments” (Keating 2003, 281). In a similar vein, with regard to isolating the barriers or problems regarding NQF, these have been described as epistemological, political, and institutional (Raffe et al. 2007), or, when described as problems, they have been categorized into political, 
administrative and educational (Young 2008). Practically then, there are immense complexities isolating both what NQFs are having an impact on, and regarding what is preventing NQFs from having an 'impact'.

Another practical issue is that involved in reaching all stakeholders. Stakeholders are often written or talked about but rarely defined (e.g. Coles 2010), yet exactly who the stakeholders are for NQFs is a good question. If this is not known, then the 'impact' of NQFs cannot be measured (see above).

Thus, in terms of methodological / philosophical and method / practical issues, trying to measure the 'impact' of NQFs is an impossible dream. Philosophically, issues such as the complexity of cause and effect and the impossible dreams NQFs themselves are attempting to pursue mitigate against any reliable or valid ability to ascertain 'impact'. Practically, issues such as the inability to identify stakeholders and the inability to see the whole picture of NQFs in the face of the volume of research in existence make any attempt to measure 'impact' equally impossible. When such factors are considered alongside the linguistic and semantic considerations and the lack of homogeneity of NQFs outlined above, the impossibility of ascertaining a yardstick to measure the impact of NQFs clearly shows that any attempt to do so is an impossible dream.

\section{Conclusion. Time to stop dreaming.}

In this article we have argued that trying to measure the 'impact' of National Qualifications Frameworks is a dream that it is impossible to ascertain a suitable yardstick for. We did this from three broad themes: linguistically and semantically considering the term 'impact' in the context of NQFs; highlighting the (lack of) homogeneity of NQFs and; considering the methodological complexities of researching the 'impact' of NQFs. Linguistically and semantically, we noted how the term 'impact' has numerous complexities. We noted how it may be more appropriate to research 'resistance', and that semantically, an NQF could, paradoxically, have more 'impact' if it fails to have any impact. Further, we noted how unclear it is regarding precisely who the NQF should be having an impact on.

Regarding the lack of homogeneity of NQFs, we showed the huge heterogeneity of NQF classifications. We also showed how the way in which these descriptions are used can vary, and showed how frameworks often exist along a continuum rather than as delineable entities. We also noted the confounding factors of 'time', of how NQFs develop, of levels, the issue of how change is introduced and, range of terms used to describe NQFs.

Finally, in terms of methodological issues, we showed how philosophically, issues such as the complexity of ascertaining cause or effect and the impossible dreams NQFs themselves are pursuing mitigate against any reliable or valid ability to ascertain 'impact'. When taken together, these three themes underline what we have argued to be the impossible dream of trying to ascertain a suitable yardstick by which 
to measure the 'impact' of National Qualifications Frameworks. In moving forward, our intention is to point out a clear need to better explain and argue a case for measuring the 'impact' of NQFs and understand whose interest such work privileges. Further, to define exactly what 'impact' means in the context of NQFs and to recognise that the different contexts of NQFs may defy any attempt to define impact and other terms since they are used so very differently depending on the context.

In turn, such questions raise more fundamental questions we argue would be of value to consider in future research. For example, what value is there in implementing a policy for which the impact cannot be measured? Is it indeed the case, as has been alluded to elsewhere (Fernie et al. 2103), that NQFs are simply marketing tools to grow student populations in an increasingly global higher education? Do policy makers assume the claims that NQFs make are still valid? If so why? Is there an alternative to NQFs and other similar type policies? More importantly perhaps, does there need to be?

\section{References:}

Allais, S. 2003. "The National Qualifications Framework in South Africa: a democratic project trapped in a neo-liberal paradigm.” Journal of Education and Work 16 (3): $305-323$.

Allais, S. M. 2007a. "Why the South African NQF Failed: Lessons for Countries Wanting to Introduce National Qualifications Frameworks.” European Journal of Education 42 (4): 523-547.

Allais, S. 2007b. "Education service delivery: the disastrous case of outcomes-based qualifications frameworks.” Progress in Development Studies 7 (1): 65 - 78.

Allais, S. 2010. "The impact and implementation of NQFs: report of a study in 16 countries." Geneva: ILO

Allais, S. 2011. "The impact and implementation of national qualifications frameworks: a comparison of 16 countries.” Journal of Education and Work 24 (34): 233-259.

Bakhtin, M. 1981. "The dialogic imagination.” Austin: University of Texas Press.

Bakhtin, M. M., M. Holquist, V. McGee, V., and C. Emerson. 1986. "Speech genres and other late essays." Austin: University of Texas Press.

Bennet, S and P. Ryley. 2007. "The Bologna Process And Lifelong Learning: Complexity And Flexibility As Watchwords For Change.” Journal of Adults and Continuing Education 13 (2): 213 - 230.

Blackmur, D. 2004. “Issues in higher education quality assurance.” Australian Journal of Public Administration 63 (2): 105 - 116.

Blackmur, D. 2010. “Does the Emperor Have the Right (or Any) Clothes?” Quality in Higher Education 16 (1): 67 - 69

Bohlinger, S. 2008. "Competences as the core element of the European Qualifications Framework.” European Journal of Vocational Training 42 (3) 43 (1) Cedefop European Centre for the Development of Vocational Training, pp 96 - 118.

Bologna Process. 2009. "Bologna Process. Development of Qualifications Frameworks. Meeting of national correspondents” Strasbourg: Council of Europe. DGIV/EDU/HE (2009) OJ 10

Borges, J. L., G. N. T. Di, A. Reid, and J.L. Borges. 1979. “The book of sand”; translated [from the Spanish] by Norman Thomas de Giovanni; [and], "The gold of 
the tigers: selected later poems"; translated [from the Spanish] by Alastair Reid /[by] Jorge Luis Borges. London: Allen Lane.

Bouder, A. 2003. “Qualifications in France: towards a national framework?” Journal of Education and Work 16 (3): 347 - 356.

Brown, K. 2010. "The relevance of the EQF to Scotland.” Presentation delivered at the conference 'Referencing the UK frameworks to the European Qualifications Framework for Lifelong Learning.' Report of the UK EQF launch Conference Edinburgh, 26-27 April, 2010. Compiled on behalf of: UK National Co-ordination Points. pp 7-9.

Bjørnåvold, J, and M. Coles. 2008. "Governing education and training; the case of qualifications frameworks” European Journal of Vocational Training 42 (3) 43 (1) Cedefop - European Centre for the Development of Vocational Training, pp 203235.

Calleja, J. 2008. "Linking VET and higher education. Is the EQF contributing to this issue?” European Journal of Vocational Training 42 (3) 43 (1) Cedefop European Centre for the Development of Vocational Training, pp 156 - 166.

Clegg, S. 2010. "Time future - the dominant discourse of higher education” Time \& Society 19 (3): 345-364

Cohen-Vogel, L. and Ingle, W.K. 2007. "When neighbours matter most: innovation, diffusion and state policy adoption in tertiary education.” Journal of Education Policy, 22 (3): 241-262.

Coles, M. 2007. “Qualifications frameworks in Europe: platforms for collaboration, integration and reform." Paper for the conference: Making the European learning area a reality, 3-5 June, Munich.

Coles, M. 2010b. “The EQF: a European: a European tool for transparency and mobility.” Presentation delivered on behalf of Gordon Clark at the conference 'Referencing the UK frameworks to the European Qualifications Framework for Lifelong Learning.' Report of the UK EQF launch Conference Edinburgh, 26-27 April, 2010. Compiled on behalf of: UK National Co-ordination Points. pp 5 - 6 .

CEDEFOP. 2008. European Journal of Vocational Training 42 (3) 43 (1) Cedefop European Centre for the Development of Vocational Training.

Dobbins, M., and Knill, C. 2009. "Higher education policies in Central and Eastern Europe: convergence toward a common model?” Governance, 22(3): 397-430.

Dunkel, T and I. Le Mouillour. 2008. "Qualifications frameworks and credit systems: a toolkit for education in Europe.” European Journal of Vocational Training 42 (3) 43 (1) Cedefop - European Centre for the Development of Vocational Training, pp $184-202$.

Ensor, P. 2003. “The National Qualifications Framework and Higher Education in South Africa: some epistemological issues.” Journal of Education and Work 16 (3): $325-346$.

Fairclough, N. 2006. “Language and Globalization.” London: Routledge

Fernie, S., and N. Pilcher. 2009. "National Qualification Frameworks: Developing Research Perspectives.” Quality in Higher Education, 15 (3): 221-232.

Fernie, S., N. Pilcher, and K.L. Smith. 2013. "The Scottish Credit and Qualifications Framework: what's academic practice got to do with it?” European Journal of Education 49 (2): 233 - 248.

Filippakou, O and T. Tapper. 2007. "Quality Assurance in Higher Education: Thinking Beyond the English Experience.” Higher Education Policy 20 (3):339 360. 
Findlow, S. 2008. "Accountability and innovation in higher education: a disabling tension?” Studies in Higher Education 33, (3): 131 - 329.

Foucault, M. 2000. "Truth and juridical forms.” In Essential works of Foucault. (Vol. 3).” Edited by J.D. Faubion, 7 - 87. New York, NY: New Press.

Gibson, A. 1986 “Inspecting Education.” In "Standards and criteria in higher education.” Edited by G.C. Moodie, 128 - 135. Philadelphia: Society for Research into Higher Education.

Grant, K. 2003. "Making sense of education change at Thistle College: the existence of witchcraft, witches and shamans.” The International Journal of Educational Management 17 (2): $71-83$

Granville, G. 2003. "'Stop Making Sense': chaos and coherence in the formulation of the Irish qualifications framework.” Journal of Education and Work 16 (3): 259 270

Hartley, D. 2006. "Pulling us apart? Relativism and instrumentalism in contemporary educational research.” Educational Review 58 (3): 269-272.

Hodson, $\mathrm{P}$ and H. Thomas. 2003. "Quality Assurance in higher education: fit for the new millennium or simply year 2000 compliant?” Higher Education 45 (3): 375387

Hozjan, D. 2008. "European qualifications framework influences on a national framework: the case of Slovenia.” European Journal of Vocational Training 42 (3) 43 (1) Cedefop - European Centre for the Development of Vocational Training, pp $143-155$

Karran, T. 2007. "Academic Freedom in Europe: A Preliminary Comparative Analysis.” Higher Education Policy 20 (3): 289 - 313.

Keating, J. 2003. "Qualifications Frameworks in Australia.” Journal of Education and Work 16 (3): 271 - 288

Keating, J. 2011. “The Malaysian Qualifications Framework. An Institutional Response to Intrinsic Weaknesses.” Journal of Education and Work 24 (3-4): 393407.

Keevy, J. 2010. “An international perspective: the NQF in South Africa.” Presentation given at the UK EQF Launch Conference: Referencing the UK frameworks to the European Qualification Framework Report of the Edinburgh Conference, 26-27 April, 2010. Compiled on behalf of: UK National Co-ordination Points. pp $9-10$.

Lauder, H. 2011. "Education, Economic Globalisation and National Qualifications Frameworks.” Journal of Education and Work 24 (3-4): 213-221.

Liesner, A. 2006. "Education or Service? Remarks on teaching and learning in the entrepreneurial university.” Educational Philosophy and Theory 38 (4): 483 - 495.

Machiavelli, N. 1532. "The Prince.” Florence: Antonio Blado d'Asola

Maclennan, A., M. Dundas, K. Musselbrook, Scottish Further Education Funding Council., and Scottish Higher Education Funding Council. 2000. "Credit transfer at the FE/HE interface: Widening opportunities: research report for the Scottish Higher Education Funding Council.” Edinburgh: Scottish Higher Education Funding Council.

Magalhaes, A.M and A. Amaral. 2007. "Changing Values and Norms in Portuguese Higher Education.” Higher Education Policy 20 (3): 315 - 338

Marock, C. 2011. “The NQF in Mauritius.” Journal of Education and Work, 24 (3-4): 409-427.

Markowitsch,J and K. Luomi-Messerer. 2008. "Development and interpretation of descriptors of the European Qualifications Framework.” European journal of 
vocational training 42 (3) 43 (1) Cedefop - European Centre for the Development of Vocational Training, pp 33 - 58

Moon, J. 2002. "The Module and Program Development Handbook: A practical guide to linking levels, outcomes and assessment criteria." Oxford: Routledge

National Advisory Body for Local authority Higher Education. 1984. "Quality” London: NAB, mimeo

Neave, G. 2002. "Editorial. Academic freedom in an age of globalisation.” Higher Education Policy 15 (4): 331 - 335

Oxford Dictionaries (n.d.) "Definition of 'Impact'.” Available from http://www.oxforddictionaries.com/ last accessed August 2014

Paulsen, M. B. 2008. "Freedom of movement: from right to possibility. Recognition of qualifications through legislation or information Review of political initiatives developed for promoting freedom of movement in the EU training and labour market.” European journal of vocational training 42 (3) 43 (1) Cedefop European Centre for the Development of Vocational Training, pp 19 - 32

Phillips, D. 2003. "Lessons from New Zealand's National Qualifications Framework.” Journal of Education and Work 16 (3): 289 - 304.

Quality Assurance Agency. 2003. "Higher Quality, 12.” London: Q AA

Raffe, D. 2003. "'Simplicity Itself': the creation of the Scottish Credit and Qualifications Framework.” Journal of Education and Work 16 (3): 239 - 257.

Raffe, D., C. Howieson, and T. Tinklin, 2007. "The impact of a unified curriculum and qualifications system: the Higher Still reform of post-16 education in Scotland.” British Education Research Journal 33 (4): 479 - 508.

Raffe, D. 2011. “Are 'Communications Frameworks'; More Successful? Policy Learning from the Scottish Credit and Qualifications Framework.” Journal of Education and Work 24 (3-4): 283-302.

Raffe, D., 2012. "What is the evidence for the impact of National Qualifications Frameworks?” Comparative Education, 49 (2): 143-162.

Raffe, D, J. Gallacher, and N. Toman, 2008. "The Scottish credit and qualifications framework: lessons for the EQF.” European journal of vocational training 42 (3) 43 (1) Cedefop - European Centre for the Development of Vocational Training, pp $59-69$

Ramsden, P. 1986. "Students and Quality”. In Standards and criteria in higher education. Edited by G.C. Moodie, 107-120. Philadelphia: Society for Research into Higher Education.

Rehburg, M. 2005. "Research report on research project with the working title 'Bachelor- und Masterstudiengänge in Deutschland: Einschätzungen von Studierenden, Professoren und Arbeitgebern. Eine qualitative Kurzstudie’” supported by the Federal Ministry for Education and Research - subsidy identification code M 1705 0. Kassel, 2005.

Republic of South Africa. 2001. "A focused study of the development of the National Qualifications Framework (NQF) with the aim of streamlining its implementation: Call for written submissions from stakeholder bodies and members of the public" (Pretoria, Government Gazette. 433).

Salter, B and T. Tapper, T. 2000. "The Politics of Governance in Higher Education: The Case of Quality Assurance. Political Studies 48 (1):66 - 87.

Saussure, F. 1959. “Course in general linguistics.” New York, NY: Philosophical Library. 
Silver, H and P. Silver, P. 1986. “The Escaping Answer” In Standards and criteria in higher education. Edited by G.C. Moodie, 9 - 30. Philadelphia: Society for Research into Higher Education.

Strathdee, R. 2011. "The Implementation, Evolution and Impact of New Zealand's National Qualifications Framework.” Journal of Education and Work, 24 (3-4): 303-321.

Strydom, J.F, N. Zulu, and L. Murray. 2004. “Quality, Culture and Change.” Quality in Higher Education, 10 (3): 207-217

Tau, D., and T.S. Modesto. 2011. "Qualifications Frameworks: Implementation and Impact in Botswana.” Journal of Education and Work, 24 (3-4): 359-373.

Tierney, L., and M. Clarke. 2008. “The European qualifications framework: challenges and implications in the Irish further education and training sector." European journal of vocational training 42 (3) 43 (1) Cedefop - European Centre for the Development of Vocational Training, pp 129-142

Tuck, R. 2007. “An Introductory Guide to National Qualifications Frameworks: Conceptual and Practical Issues for Policy Makers." Skills and Employability Department, International Labour Office (ILO) International Labour Office, CH1211 Geneva 22, Switzerland

Tutlys, V., and I. Spudyte. 2011. "Implementing a National Qualifications Framework in Lithuania.” Journal of Education and Work 24 (3-4): 429-448.

van der Wende, M.C. 2000. "The Bologna Declaration: Enhancing the Transparency and Competitiveness of European Higher Education.” Journal of Studies in International Education, 4 (2): 3-10.

Wheelahan, L. 2011. "From Old to New: The Australian Qualifications Framework." Journal of Education and Work, 24 (3-4): 323-342.

Worth Doing: Using the Scottish Credit and Qualifications Framework in Community Learning and Development. 2008. The Scottish Credit and Qualifications Framework. Smarter Scotland. The Scottish Government. Available at http://scqf.org.uk/wp-content/uploads/2014/04/Worth_Doing_-_Oct_08.pdf last accessed November 2014

Young, M. 2003. “National Qualifications Frameworks as a Global Phenomenon: a comparative perspective.” Journal of Education and Work, 16 (3): 223-237.

Young, M. 2008. "Towards a European qualifications framework: some cautionary observations.” Journal of European Industrial Training, 32 (2-3): 128 - 137.

Young, M. 2011. "The educational implications of introducing a NQF for developing countries.” Journal of Education and Work, 24 (3-4): 223-232.

Young, M and S. Allais. 2011. "Editor's introduction.” Journal of Education and Work, 24 (3-4): 209-211. 